\title{
Effects of selective insecticides on host searching and oviposition behavior of Neochrysocharis formosa (Westwood) (Hymenoptera: Eulophidae), a larval parasitoid of the American serpentine leafminer
}

\author{
Dang Hoa Tran, ${ }^{1}$ Masami TAKAgI ${ }^{2, *}$ and Keiji TAKASU ${ }^{2}$ \\ ${ }^{1}$ Graduate School of Bioresource and Bioenvironmental Sciences, Kyushu University; Fukuoka 812-8581, Japan \\ ${ }^{2}$ Faculty of Agriculture, Kyushu University; Fukuoka 812-8581, Japan
}

(Received 17 December 2003; Accepted 22 March 2004)

\begin{abstract}
Effects of application of three insecticides (imidacloprid, pymetrozine and lufenuron) on host searching and oviposition behavior of Neochrysocharis formosa (Westwood), a larval parasitoid of the American serpentine leafminer Liriomyza trifolii (Burgess), were investigated in the laboratory. Female wasps spent more than $89 \%$ of their time on a leaf of host-infested kidney bean when introduced into a container containing the leaf treated with each insecticide or distilled water. However, wasps spent more time resting near or away from hosts and less time foraging for hosts on the leaves treated with imidacloprid than the other treated leaves. As a result, they encountered, oviposited and fed on hosts less frequently with imidacloprid treated leaves than any other treated leaves. The numbers of host findings, ovipositor insertions and host feedings were also significantly lower on the leaves treated with lufenuron than the control. These results suggest that imidacloprid and lufenuron reduced wasp host searching efficiency.
\end{abstract}

Key words: Insecticides; indirect effects; leafminer; Neochrysocharis formosa; behavior

\section{INTRODUCTION}

Pesticides currently play a major role in crop pest control, either as independent control agents or as a component of an integrated pest management (IPM) system (Umoru and Powell, 2002). However, insecticides such as organophosphates, carbamates, and synthetic pyrethroids are generally highly toxic to biological control agents, due to their broad spectrum of activity (Croft, 1990). Other insecticides that do not appear to kill natural enemies, may also have sub-lethal effects, such as altered behavior, reduced reproduction, and reduced longevity, on natural enemies (Jacobs et al., 1984; Elzen, 1989; Croft, 1990; Longley and Jepson, 1996). In IPM, therefore, it is important to examine the possible disruptive effects of candidate insecticides on beneficial insects, and to determine the insecticides compatible with key biological control agents (Stapel et al., 2000). The compatibility of an insecticide with biological control agents is often examined by tests screening for mortality of natural enemies, but sub-lethal effects on beneficial insects are largely overlooked (Elzen, 1989).

Liriomyza trifolii (Burgess) (Diptera: Agromyzidae), native to North and South America, is a serious pest of numerous ornamental and vegetable crops worldwide (Parrella and Jones, 1987; Spencer, 1989, 1990) Conventional control of this pest has been dependent on synthetic chemical insecticides, including chlorfenapyr, chlorfluazuron, chlorpyriphos-etyl, deltamethrin, diazinon, edosulfan, malathion, abamectin and cyromazine (Civelek and Weintraub, 2003). However, L. trifolii has developed resistance to a wide range of insecticides (Keil and Perrella, 1990), and thus alternative control measures are needed.

Neochrysocharis formosa (Westwood) (Hymenoptera: Eulophidae) is an endoparasitoid that attacks larvae of leafminers and eggs of sawflies (Yoshimoto, 1978; Hasson, 1990, 1995). In Japan, $N$. formosa is predominant among the parasitoids attacking L. trifolii (Burgess) in Kyushu, and has

* To whom correspondence should be addressed at: E-mail: mtakagi@agr.kyushu-u.ac.jp DOI: $10.1303 / \mathrm{aez} .2004 .435$ 
been recognized as an effective biological control agent of leafminers in tomato, bean and eggplant (Saito et al., 1996; Arakaki and Kinjo, 1998; Ohno et al., 1999; Mariana, 2000). Although both sexual and asexual strains of $N$. formosa are present in Kyushu, the asexual strain is a good biological control agent because this strain has a higher rate of population increase than the sexual one (Arakaki and Kinijo, 1998; Mariana, 2000).

The objective of this study was to determine if conventional insecticides that are supposedly safe to natural enemies and used for IPM programs have sublethal effects on natural enemies. Since imidacloprid, lufenuron and pymetrozine are recommended for IPM programs because of their high selectivity, we examined possible effects of these insecticides on host searching and oviposition behavior of $N$. formosa. Imidacloprid and pymetrozine are commonly used for controlling sucking pests such as Aphis gossypi, Brevioryne brassicaei, Bemisia argentifolii, Thrips tabaci and Caliothrips brasiliensis (Bethke and Redak, 1997; Marquini et al., 2002; Sechser et al., 2002; Ester et al., 2003). Lufenuron is currently available for lepidopteran pests including Spodoptera littoralis, $\mathrm{Ph}$ thorimaea operculella and Lacanobia oleracae (Javaid et al., 1999; Edomwande et al., 2000; Whiting et al., 2000; Butter et al., 2003). These pests and the leafminers often co-exist in fields of various vegetables and ornamental crops, including tomato, melon, cucumbers, eggplants, green pepper, peach, chrysanthemum, apple and strawberry (Sibanda et al., 2000; van Lenteren, 2000; Marquini et al., 2002).

\section{MATERIALS AND METHODS}

Insect. L. trifolii was reared on the kidney bean, Phaseolus vulgaris L., in the same manner as described by Giang and Ueno (2002). A single seed of this plant was sown in a plastic pot $(7.5 \mathrm{~cm}$ in diameter) and kept at $25^{\circ} \mathrm{C}$ and $60-70 \%$ humidity under constant light. One week after germination, a tray $(32 \mathrm{~cm} \times 44 \mathrm{~cm} \times 6 \mathrm{~cm})$ containing 24 potted plants was placed on a shelf $(200 \mathrm{~cm} \times 60 \mathrm{~cm} \times$ $50 \mathrm{~cm}$ ) covered with a fine nylon mesh. Leafminer adults were released inside the mesh and allowed to oviposit on the plants for $24 \mathrm{~h}$. Thereafter, the potted plants were maintained under the same conditions until all leafminer larvae feeding on the plants reach the last instar. The leaves containing final-instar larvae were cut off and kept in a polyethylene terephthalate (PET) bottle (1.5l in volume) to gain adult leafminers.

Parasitoid. The asexual strain of the parasitoid $N$. formosa used for the present study originated from a culture that was reared from $L$. trifolli mines collected in August 1997 from Kagoshima Prefecture by the Fukuoka Agricultural Research Center, Fukuoka, Japan. This parasitoid was maintained with the final-instars of $L$. trifolii at $25^{\circ} \mathrm{C}$ with $60-70 \%$ humidity and 16L : 8D. Each leaf of kidney bean plants $(15-20 \mathrm{~cm}$ in height) was infected with 30-50 s and third instar larvae of L. trifolii. For parasitization, 6 host-infested plants and a piece of tissue paper $(2 \mathrm{~cm} \times 2 \mathrm{~cm})$ saturated with a honey solution were placed in a plastic cage $(35 \mathrm{~cm} \times 20 \mathrm{~cm} \times 25 \mathrm{~cm})$ covered with a fine nylon mesh. About 100-300 parasitoids were introduced into the cage. After exposure for $24 \mathrm{~h}$, these plants were relocated to a plastic container $(60 \mathrm{~cm} \times$ $50 \mathrm{~cm} \times 40 \mathrm{~cm}$ ) until pupation of the parasitoids (approximately 6 days after parasitism). The kidney bean leaves with parasitoid pupae were removed from the plant stems and placed into a PET bottle ( $1 l$ in volume). Emergence of parasitoids was checked daily. Female wasps were provided honey immediately after emergence.

Insecticides. The commercial formulations of three insecticides, imidacloprid (Admire 10WP), pymetrozine (Chess 25WP) and lufenuron (Match 5EC) were diluted with distilled water and applied at the following field rates. The field rate for each insecticide was based on the recommended label rate assuming an application volume of $0.5 \mathrm{~g} / l$ of water for imidacloprid and pymetrozine, and of $0.25 \mathrm{ml} / l$ of water for pymetrozine. Medium size $\left(20-30 \mathrm{~cm}^{2}\right)$ kidney bean leaves that were infested with second host instar larvae (approximately 3 days after releasing leafminer adults) were selected. The insecticides were sprayed on both under and upper sides of the leaves (approximately $3 \mathrm{ml} /$ plant with 2 leaves) with a power-pack aerosol hand sprayer (Hand Spray Nozzle, Takeda Engei Co., Japan). As a control, distilled water was applied to host infested plants in the same way as the insecticides. After leaves were completely dry, within $24 \mathrm{~h}$ of spraying, the control and treated plants were used for the following experiments.

Experimental procedures. The leaves treated 
with insecticides or distilled water described above were infested with 3-8 third instar hosts (yellowish green in color, approximately $2.5 \mathrm{~mm}$ in length). Individual parasitoid females within 2 days after emergence were introduced into a truncated-coneshaped plastic container $(8 \mathrm{~cm}$ in bottom diameter, $10 \mathrm{~cm}$ in top diameter and $5.5 \mathrm{~cm}$ in height) containing a treated leaf. The container possessed small holes $(1.5 \mathrm{~cm}$ in diameter) covered with thin muslin cloth on its sides for ventilation. We observed behavior of females for $30 \mathrm{~min}$ after they landed on the leaf under the binocular microscope.

The sequence of host searching and oviposition behavior is shown in Fig. 1. After landing on a leaf, a female wasp drummed the leaf surface with her antenna. She sometimes inserted her ovipositor through the epidermis of the leaf while walking. When she encountered a host mine, she walked along the mine while drumming the mine (host mine drumming) and inserted her ovipositor into the mine to find a host larva (host mine probing). When she found a host larva in the mine, she inserted her ovipositor to lay an egg or fed on the host. The female usually laid one egg in a host. When females again encountered the hosts parasitized by themselves, they often left them without oviposition but occasionally oviposited again in them. For host feeding, the female first inserted her ovipositor into a host larva, withdrew it and then fed on the hemolymph oozing from the host. Moreover, a female repeated ovipositor insertion, withdrawing and feeding on the same host 3 to 15 times $(n=7$; Mean $\pm \mathrm{SD}=8.2 \pm 3.5)$. However, she did not use the same host for both feeding and oviposition (non-concurrent host feeding type, Jervis and Kidd, 1986).

We separated female behavior observed on leaves into the following 7 events. Walking: a female walked not on the host mines but other parts of a leaf. Host mine drumming: when a female found a host mine, she walked along the host mine while drumming the mine surface with her antennae. Host mine probing: a female inserted her ovipositor through a host mine or other part of the leaf surface. Host drumming: when a female found a host in a mine, she walked back and forth around the host while drumming it with her antennae. Oviposition: once a female located a host, she inserted her ovipositor into the host to lay an egg. Host feeding: after probing a host, a female in-

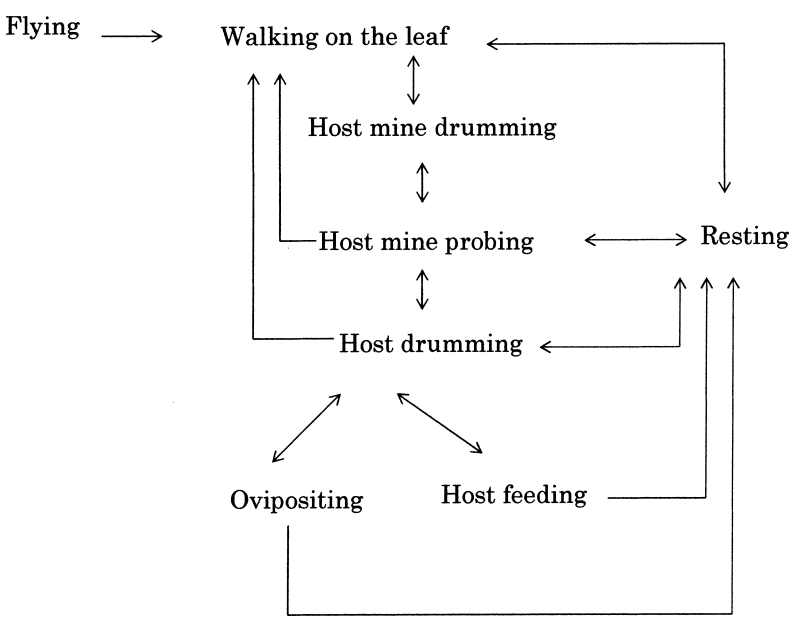

Fig. 1. Behavioral sequence of $N$. formosa females.

serted her ovipositor into the host larva, withdrew it and then fed on the hemolymph exuding from the host wound. Resting: a female rested near or away from a host on a leaf and often groomed.

The behavioral sequence and the duration of each behavioral event were recorded. The duration of host feeding was recorded as the period from encountering a host to departing from the host after feeding. All experiments were done between 14:00 and $18: 00$ at $25^{\circ} \mathrm{C}$ with $60-70 \%$ humidity. A total of 20 females were observed for each treatment. After the observations, the hosts attacked by parasitoids were dissected to confirm whether parasitoids oviposited into the host. The area of observed leaves was also measured.

Statistical analysis. The percentages were arcsine-transformed and then analyzed by a one wayANOVA. The means were separated by Fisher's PLSD test (SAS Institute, 1998).

\section{RESULTS}

\section{Effect of insecticides on time stayed on host in- fested leaves}

During a $30 \mathrm{~min}$ observation, females spent more than $89 \%$ of their time on the treated or control leaves searching for hosts. They occasionally flew or walked off the leaf. There was no significant difference in time spent on the leaf between the treatments $(\mathrm{df}=3,76, F=0.69, p>0.05)$ (Table $1)$.

\section{Effects of insecticides on time allocation}

The parasitoid spent less time walking, oviposi- 
tion and host drumming, but spent more time resting on leaves treated with imidacloprid than on leaves treated with other insecticides and water. There was no significant difference $(p>0.05)$ in time spent for these three behavioral components among pymetrozine, lufenuron and water treat-

Table 1. Effect of insecticides on the percentage of time spent in host location of $N$. formosa females during $30 \mathrm{~min}(\mathrm{Mean} \pm \mathrm{SD})$

\begin{tabular}{ll}
\hline Treatments & Time on leaf \\
\hline Imidacloprid & $89.19 \pm 22.01 \mathrm{a}$ \\
Pymetrozine & $96.25 \pm 12.54 \mathrm{a}$ \\
Lufenuron & $95.31 \pm 8.78 \mathrm{a}$ \\
Water & $92.73 \pm 13.46 \mathrm{a}$
\end{tabular}

Means with the same letter within a column are not significantly different by Fisher's PLSD after one-way ANOVA, $p<0.05, n=20$. ments. The parasitoid, however, spent no time on host feeding in imidacloprid and lufenuron treatments (Table 2).

\section{Effects of insecticides on host foraging efficiency}

Mean number of hosts encountered was significantly different among the treatments $(\mathrm{df}=3,76$, $F=9.39, p<0.05$ ) (Table 3). Females found fewer hosts in imidacloprid and lufenuron leaves than pymetrozine and control leaves $(p<0.05)$.

Mean number of ovipositor insertions into hosts was significantly different among the treatments $(\mathrm{df}=3,76, F=8.29, p<0.05)$ (Table 3). Females inserted ovipositors into hosts less frequently for imidacloprid and lufenuron than for pymetrozine and the control $(p<0.05)$.

Mean number of ovipositions was also significantly different among the treatments $(\mathrm{df}=3,76$, $F=9.67, p<0.05)$ (Table 3). Females oviposited in

Table 2. Effect of insecticides on the percentage of time taken for behavioral events of $N$. formosa females on infested leaves during 30 min observation periods (Mean \pm SD)

\begin{tabular}{|c|c|c|c|c|}
\hline \multirow{2}{*}{ Behavior } & \multicolumn{4}{|c|}{ Treatment } \\
\hline & Imidacloprid & Pymetrozine & Lufenuron & Water \\
\hline Walking on leaf & $3.9 \pm 4.8 \mathrm{a}$ & $7.5 \pm 6.9 \mathrm{~b}$ & $8.9 \pm 6.4 b$ & $7.6 \pm 5.4 \mathrm{~b}$ \\
\hline Host mine probing & $1.2 \pm 2.1 \mathrm{a}$ & $1.4 \pm 1.6 \mathrm{ab}$ & $2.6 \pm 3.1 \mathrm{~b}$ & $1.6 \pm 1.3 \mathrm{ab}$ \\
\hline Host mine drumming & $10.7 \pm 12.3 \mathrm{a}$ & $12.6 \pm 5.9 \mathrm{ab}$ & $15.1 \pm 9.0 \mathrm{~b}$ & $18.0 \pm 11.4 \mathrm{~b}$ \\
\hline Host drumming $^{\mathrm{a}}$ & $3.7 \pm 4.4 \mathrm{a}$ & $10.8 \pm 6.9 \mathrm{~b}$ & $8.4 \pm 4.7 \mathrm{~b}$ & $10.4 \pm 4.0 \mathrm{~b}$ \\
\hline Oviposition & $7.7 \pm 10.3 \mathrm{a}$ & $22.6 \pm 14.1 \mathrm{~b}$ & $23.1 \pm 13.5 b$ & $19.1 \pm 8.7 \mathrm{~b}$ \\
\hline Host feeding & $0 \mathrm{a}$ & $1.0 \pm 4.5 \mathrm{~b}$ & $0 \mathrm{a}$ & $4.6 \pm 11.9 \mathrm{c}$ \\
\hline Resting & $62.5 \pm 30.7 \mathrm{~b}$ & $40.4 \pm 23.9 \mathrm{a}$ & $37.2 \pm 23.7 \mathrm{a}$ & $30.5 \pm 17.7 \mathrm{a}$ \\
\hline
\end{tabular}

Mean with the same letters within a row are not significantly different by Fisher's PLSD after one-way ANOVA, $p<0.05, n=20$.

${ }^{a}$ Not including drumming of hosts that were fed on.

Table 3. Effect of insecticides on host finding, oviposition and host feeding by N. formosa females during 30 min observation priods $(\mathrm{Mean} \pm \mathrm{SD})$

\begin{tabular}{lcccc}
\hline Treatment & No. of hosts found & $\begin{array}{c}\text { No. of ovipositor } \\
\text { insertions in hosts }\end{array}$ & No. of eggs laid & No. of hosts fed on \\
\hline Imidacloprid & $1.10 \pm 0.97 \mathrm{a}$ & $1.95 \pm 2.37 \mathrm{a}$ & $0.65 \pm 0.99 \mathrm{a}$ & $0 \mathrm{a}$ \\
Pymetrozine & $2.60 \pm 1.50 \mathrm{bc}$ & $6.89 \pm 5.63 \mathrm{c}$ & $2.15 \pm 1.27 \mathrm{~b}$ & $0.05 \pm 0.22 \mathrm{~b}$ \\
Lufenuron & $2.10 \pm 1.21 \mathrm{~b}$ & $4.68 \pm 2.72 \mathrm{~b}$ & $1.95 \pm 1.28 \mathrm{~b}$ & $0 \mathrm{a}$ \\
Water & $3.05 \pm 1.15 \mathrm{c}$ & $5.63 \pm 2.41 \mathrm{bc}$ & $2.35 \pm 0.81 \mathrm{~b}$ & $0.25 \pm 0.44 \mathrm{c}$ \\
\hline
\end{tabular}

Means with the same letters within a column are not significantly different by Fisher's PLSD after one-way ANOVA, $p<0.05$, $n=20$.

${ }^{\text {a }}$ Not including the number of insertions into the hosts fed on.

${ }^{\mathrm{b}}$ Includes superparasitism. 
fewer hosts for imidacloprid than for any other treatments $(p<0.05)$.

There was a significant difference in the number of hosts feeding among the treatments $(\mathrm{df}=3,76$, $F=4.58, p<0.05$ ) (Table 3 ). Females fed on hosts more often in the control than the other treatments $(p<0.05)$.

\section{DISCUSSION}

Insecticides can upset the very precise coordination between the insect nervous and hormonal systems and have an effect on a complex series of behavioral and physiological events related to oviposition and feeding (Haynes, 1988). Insecticides are known to cause irritancy, locomotory depression and repellency in parasitoids, resulting in diminished oviposition and host feeding success (e.g. Franz and Fabrietius, 1971; Irving and Wyatt, 1973; Perera, 1982; Singh and Varma, 1986; Haynes, 1988; Croft, 1990; Rogers and Potter, 2003). The present study also showed adverse effects of insecticides on searching and oviposition behavior of $N$. formosa. The parasitoid females spent more time resting near or away from hosts and less time foraging for hosts on the leaves treated with imidacloprid than the other treated leaves (Table 2). We observed that some females often groomed during resting and others stood still for a long time. These observations indicate that imidacloprid has irritant and locomotory depression effects on this wasp. The grooming behavior is thought to be a reflex action initiated by an irritant to chemoreceptors or mechanoreceptors located on the insect body surface (Reingold and Camhi, 1978). These grooming or cleaning behaviors remove contaminates from the irritated areas (Gratwick, 1957). Rogers and Potter (2003) demonstrated that imidacloprid caused grooming behavior in the parasitoid Tiphia vernalis by interfering with the antennal receptors, thereby extending grooming of antennae and inhibiting host recognition. When $N$. formosa females are exposed to imidacloprid treated leaves, they may groom to remove and emanate the insecticide. In addition, imidacloprid caused $N$. formosa females to spend a greater proportion of their time resting. These facts suggest that this chemical acts as a locomotory depression through intoxicating effects. Imidacloprid has also been shown to reduce mobility of the predators, Coleomegilla maculate (Smith and Krischik, 1999) and Harpalus pennsylvanicus (Kunkel et al., 2001). Imidacloprid is a neonicotinoid insecticide acting mainly through ingestion and contact. Its high activity is brought about by binding to nicotinergic acetylcholine receptors in the insect nervous system (Marquini et al., 2002).

Previous studies indicated repellent responses of parasitoids to insecticide residues (e.g. Irving and Wyatt, 1973; Perera, 1982; Jiu and Waage, 1990; Longley and Jepson, 1996; Umoru et al., 1996). However, we did not observe parasitoids attempting to escape from the observation cage during this study. It is unclear whether these insecticides caused repellent responses in $N$. formosa because our experiments were conducted under confined conditions.

Lufenuron also had adverse effects on host searching activities of $N$. formosa. Time allocated for host feeding and the number of host feedings on lufenuron treated leaves was significantly smaller than those on the control. Although time allocated for host searching and oviposition on lufenuron treated leaves did not differ from the control, the number of hosts found and host feedings on lufenuron treated leaves were smaller than for the control. This indicates that lufenuron causes behavioral changes in this parasitoid. However, how these effects are caused is still unclear at this point.

In addition to acute effects of insecticides, the insecticides that cause a reduction in host searching activity may have further adverse effects on subsequent longevity and fecundity of the parasitoid. For synovigenic parasitoids, there is a tight link between feeding by adults and subsequent reproduction (Haynes, 1988). Since host blood is superior as a source of proteinaceous materials, essential vitamins and salts for egg development (Jervis and Kidd, 1986; Heimpel and Collier, 1996), and a valuable source of nutrition for maintaining metabolism (Jervis and Kidd, 1986; Jervis et al, 1996) in host-feeding species, host-feeding parasitoids generally have reduced life time fecundity and longevity without host-feeding (Jervis and Kidd, 1986). Mariana (2000) reported that the asexual strain of $N$. formosa frequently host-feeds, and $65 \%$ of host mortality is caused by this parasitoid. Although there is no studies on the effects of host feeding on longevity and fecundity of $N$. 
formosa, reduction of host feeding frequency caused by imidacroplid and lufenuron would likely reduce fecundity and longevity.

It has been recommended that these insecticides are selective for control of target pests and should be used to control aphids, thrips, whitefly, tuber moth and Spodoptera species in conjunction with IPM on vegetable and ornamental crops where leafminers often co-exist with the pests. These chemicals are supposedly safe for the complete spectrum of beneficial arthropods, but have excellent efficacy against target pests. However, imidacloprid and lufenuron had adverse effects on host foraging behavior of $N$. formosa. Thus, although these chemicals are not to target $L$. trifolii, the application may affect the effectiveness of $N$. formosa as a biological control agent of leafminers.

\section{ACKNOWLEDGEMENTS}

We thank Dr. H. Takemoto (Fukuoka Agricultural Research Center) for providing $N$. formosa. We also thank Ms. Y. Ayabe and Mr. M. Uefune for practical assistance in rearing insects and applying insecticides.

\section{REFERENCES}

Arakaki, N. and K. Kinjo (1998) Notes on the parasitoid fauna of the serpentine leafminer Liriomyza trifolii (Burgess) (Diptera: Agromyzidae) in Okinawa, Southern Japan. Appl. Entomol. Zool. 33: 577-581.

Bethke, J. A. and R. A. Redak (1997) Effect of imidacloprid on the silverleaf whitefly, Bemisia argentifolii (Bellows and Perring) (Homoptera: Aleyrodidae), and whitefly parasitism. Ann. Appl. Biol. 130: 397-407.

Butter, N. S., G. Singh and A. K. Dhawan (2003) Laboratory evaluation of the insect growth regulator lufenuron against Helicoverpa armigera on cotton. Phytoparasitica 31: 200-203.

Civelek, H. S. and P. G. Weintraub (2003) Effects of bensultap on larval serpentine leafminers, Liriomyza trifolii (Burgess) (Diptera: Agromyzidae), in tomatoes. Crop Prot. 22: 479-483.

Croft, B. A. (1990) Arthropod Biological Control Agents and Pesticides. Wiley, New York. 723 pp.

Edomwande, E. O., A. S. Schoeman, J. A. Brits and M. van der Merwe (2000) Laboratory evaluation of lufenuron on immature stages of potato tuber moth (Lepidoptera: Gelechiidae). J. Econ. Entomol. 93: 1741-1743.

Elzen, G. W. (1989) Sub-lethal effect of pesticides on beneficial. In Pesticides and Non-target Invertebrates (P. C. Jepson ed.). Intercept Limited, Dorset, England, pp. 129150 .

Ester, A., H. de Putter and J. G. P. M. van Bilsen (2003) Filmcoasting the seed of cabbage (Brassica oleracae L. convar. capitata L.) and caufiflower (Brassia oleracae L. var. botrytis L.) with immidaclopid and spinosad to con- trol insect pests. Crop Prot. 22: 761-768.

Franz, J. M. and K. Fabrietius (1971) Testing the sensitivity to pesticides of entomophagous arthropods-trails using Trichogramma. Z. Angew. Entomol. 68: 278-288.

Giang H. T. T. and T. Ueno (2002) Biology of Hemiptarsenus varicornis (Hymenoptera: Eulophidae), a parasitoid wasp of the leafminer Liriomyza trifolli (Diptera: Agromyzidae). J. Fac. Agr., Kyushu Univ. 47: 45-54.

Gratwick, M. (1957) The contamination of insects of different species exposed to dust deposits. Bull. Entomol. Res. 48: 741-753.

Hasson, C. (1990) A taxonomic study on the palearctic species of Chrysonotomyia Ashmead and Neochrysocharis Kurdjumov (Hymenoptera: Eulophidae). Entomol. Scand. 21: 29-52.

Hasson, C. (1995) Revision of the Nearctic species of Neochrysocharis Kurdjumov (Hymenoptera: Eulophidae). Entomol. Scand. 26: 27-46.

Haynes, F. K. (1988) Sublethal effects of neurotoxic insecticides on insect behavior. Annu. Rev. Entomol. 33: 149168.

Heimpel, G. E. and T. R. Collier (1996) The evolution of host-feeding behaviour in insect parasitoids. Biol. Rev. 71: 373-400.

Irving, S. N. and I. J. Wyatt (1973) Effect of sublethal doses of pesticides on the oviposition behavior of Encarsia formosa. Ann. Appl. Biol. 75: 57-62.

Jacobs, R. J., C. A. Kouskilekas and H. R. Gross (1984) Response of Trichogramma pretiosum (Hymenoptera: Trichogrammatidae) to residues of permethrin and endosulfan. Environ. Entomol. 13: 355-358.

Javaid, I., R. N. Uaie and J. Massua (1999) The use of insect growth regulators for the control of insect pests of cotton. Int. J. Pest Manag. 45: 245-247.

Jervis, M. A. and N. A. C. Kidd (1986) Host-feeding strategies in hymenopteran parasitoids. Biol. Rev. 61: 395434.

Jervis, M. A., N. A. C. Kidd and G. E. Heimpel (1996) Parasitoid adult feeding behaviour and biocontrol-a review. Biocontrol News and Information 17: 11-26.

Jiu, G. D. and J. K. Waage (1990) The effect of insecticides on the distribution of foracing parasitoids, Diaeretiella rapae (Hym.: Braconidae) on plants. Entomophaga 35: 49-56.

Keil, C. B. and M. P. Parrella (1990) Characterization of insecticide resistance in two colonies of Liriomyza trifolii (Diptera: Agromyzidae). J. Econ. Entomol. 83: 18-26.

Kunkel, B. A., D. W. Heald and D. A. Potter (2001) Lethal and sublethal effects of bendiocarb, halofenozide, and imidaclopid on Harpalus pennsylvanicus (Coleoptera: Carabidae) following different modes of exposure in turfgrass. J. Econ. Entomol. 94: 60-67.

Longley, M. and P. C. Jepson (1996) The influence of insecticide residues on primary parasitoid and hyperparasitoid foraging behavior in the laboratory. Entomol. Exp. Appl. 81: 259-269.

Mariana, N. (2000) Studies on the ecological aspects of Neochrysocharis formosa (Hymenoptera: Eulophidae) attacking Liriomyza trifolii (Diptera: Agromyzidae). $\mathrm{PhD}$ 
thesis, Kyushu University, Japan. 132 pp.

Marquini, F., R. N. C. Guedes, M. C. Picanço and A. J. Regazzi (2002) Response of arthropods associated with the canopy of common beans subjected imidacloprid spraying. J. Appl. Entomol. 126: 550-556.

Ohno, K., T. Ohmori and H. Takemoto (1999) Effect of insecticides applications and indigenous parasitoids on population trends of Liriomyza trifolii in gerbera greenhouses. Jpn. J. Appl. Entomol. Zool. 43: 81-86 (in Japanese with English summary).

Parrella, M. P. and V. P. Jones (1987) Development of integrated pest management strategies in floricultural crops. Bull. Entomol. Soc. Am. 33: 28-34.

Perera, P. A. C. R. (1982) Some effects of insecticide deposit patterns on the parasitism of Trialeurodes vaporariorum by Encarsia formosa. Ann. Appl. Biol. 101: 239-244.

Reingold, S. C. and J. M. Camhi (1978) Abdominal grooming in the cockroach: development of an adult behavior. J. Insect Physiol. 24: 101-110.

Rogers, M. E. and D. A. Potter (2003) Effects of spring imdaclopid application for white grud control on parasitism of Japanese beetle (Coleoptera: Scarabaeidae) by Tiphia vernalis (Hymenoptera: Tiphiidae). J. Econ. Entomol. 96: 1412-1419.

Saito, T., F. Ikeda and A. Ozawa (1996) Effect of pesticides on parasitoid complex of serpentine leafminer Liriomysa trifolii (Burgess) in Shizuoka Prefecture. Jpn. J. Appl. Entomol. Zool. 40: 127-133 (in Japanese with English summary).

SAS Institute (1998) StatView 5.0J. SAS Institute Inc., Cary, NC.

Sechser, B., B. Reber and F. Bourgeois (2002) Pymetrozine: Selectivity spectrum to beneficial arthropods and fitness for integrated pest management. J. Pest Sci. 75: 72-77.

Sibanda, T., H. M. Dobson, J. F. Cooper, W. Manyangarirwa and W. Chiiba (2000) Pest management challenges for smallholder vegetable farmers in Zimbabwe. Crop Prot. 19: 807-815.

Singh, P. P. and G. C. Varma (1986) Comparative toxicities of some insecticides to Chrysoperla carnea (Chrysopidae: Neuroptera) and Trichogramma brasiliensis (Trichogrammatidae: Hymenoptera), two arthropod natural enemies of cotton pests. Agric. Ecosys. Environ. 15: 23-30.

Smith, S. F. and V. A. Krischik (1999) Effects of systemic imidacloprid on Coleomegilla maculate (Coleoptera: Coccinellidae). Environ. Entomol. 28: 1189-1195.

Spencer, K. A. (1989) Leafminers. In Plant Protection and Quarantine Vol. II. Selected Pests and Pathogens of Quarantine Significance (P. R. Kahn ed.). CRC Press, Boca Raton, FL, USA, pp. 77-98.

Spencer, K. A. (1990) Host Specialization in the World Agromyzidae (Diptera). Series Entomologica. Kluwer Ac. Pub., Dordrecht. 444 pp.

Stapel, J. O., A. M. Cortesero and W. J. Lewis (2000) Disruptive sublethal of insecticides on biological control: Altered foraging ability and life span of a parasitoid after feeding on extrafloral nectar of cotton treated with systemic insecticides. Biol. Control 17: 243-249.

Umoru, P. A. and W. Powell (2002) Sub-lethal effects of insecticides primicarb and dimethoate on the aphid parasitoid Diaeratiella rapae (Hymenoptera: Braconidae) when attacking and developing in insecticide-resistance hosts. Biocontrol Sci. Technol. 12: 605-614.

Umoru, P. A., W. Powell and S. J. Clark (1996) Effect of pirimicard on the foraging behaviour of Diaeretiella rapae (Hymenoptera: Braconidae) on host-free and infested oilseed rape plants. Bull. Entomol. Res. 86: 193-201.

van Lenteren, J. C. (2000) A greenhouse without pesticides: fact or fantasy? Crop Prot. 19: 375-384.

Whiting, D. C., L. E. Jamieson and P. G. Connolly (2000) Pre- and postharvest effects of lufenuron on Epiphyas postvittana (Lepidoptera: Tortricidae). J. Econ. Entomol. 93: 673-679.

Yoshimoto, C. M. (1978) Revision of subgenus Achrysocharella Girault of America North of Mexico (Chalcidoidea, Eulophidae: Chrysonotomyia Ashmead). Can. Entomol. 110: 697-719. 